\title{
ADHESIVES, SEALANTS, AND COATINGS FOR SPACE AND HARSH ENVIRONMENTS
}




\section{POLYMER SCIENCE AND TECHNOLOGY}

\section{Editorial Board:}

William J. Bailey, University of Maryland, College Park, Maryland

J. P. Berry, Rubber and Plastics Research Association of Great Britain, Shawbury, Shrewsbury, England

A. T. DIBenedetto, The University of Connecticut, Storrs, Connecticut

C. A. J. Hoeve, Texas A \& M University, College Station, Texas

Yolchl Ishida, Osaka University, Toyonaka, Osaka, Japan

Fran E. Karasz, University of Massachusetts Amherst, Massachusetts

Osias Solomon, Franklin Institute, Philadelphia, Pennsylvania

\section{Recent volumes in the series:}

Volume 25 NEW MONOMERS AND POLYMERS

Edited by Bill M. Culbertson and Charles U. Pittman, Jr.

Volume 26 POLYMER ADDITIVES

Edited by Jiri E. Kresta

Volume 27 MOLECULAR CHARACTERIZATION OF COMPOSITE INTERFACES

Edited by Hatsuo Ishida and Ganesh Kumar

Volume 28 POLYMER LIQUID CRYSSTALS

Edited by Alexandre Blumstein

Volume 29 ADHESIVE CHEMISTRY

Edited by Lieng-Huang Lee

Volume 30 MICRODOMAINS IN POLYMER SOLUTIONS

Edited by Paul Dubin

Volume 31 ADVANCES IN POLYMER SYNTHESIS

Edited by Bill M. Culbertson and James E. McGrath

Volume 32 POLYMERIC MATERIALS IN MEDICATION

Edited by Charles G. Gebelein and Charles E. Carraher, Jr.

Volume 33 RENEWABLE-RESOURCE MATERIALS: New Polymer Sources

Edited by Charles E. Carraher, Jr., and L. H. Sperting

Volume 34 POLYMERS IN MEDICINE II: Biomedical and Pharmaceutical Applications Edited by E. Chiellini, P. Giusti, C. Migliaresi, and L. Nicolais

Volume 35 ADVANCES IN BIOMEDICAL POLYMERS

Edited by Charles $\mathrm{G}$. Gebelein

Volume 36 FOURIER TRANSFORM INFRARED CHARACTERIZATION OF POLYMERS

Edited by Hatsuo Ishida

Volume 37 ADHESIVES, SEALANTS, AND COATINGS FOR SPACE AND

HARSH ENVIRONMENTS

Edited by Lieng-Huang Lee

A Continuation Order Plan is available for this series. A continuation order will bring delivery of each new volume immediately upon publication. Volumes are billed only upon actual shipment. For further information please contact the publisher. 


\section{ADHESIVES, SEALANTS, AND COATINGS FOR SPACE AND HARSH ENVIRONMENTS}

Edited by

Lieng-Huang Lee xerox Corporation Webster, New York 


\section{Library of Congress Cataloging in Publication Data}

International Symposium on Adhesives, Sealants, and Coatings for Space and Harsh Environments (1987: Denver, Colo.)

Adhesives, sealants, and coatings for space and harsh environments / edited by LiengHuang Lee.

p. $\quad \mathrm{cm}$.-(Polymer science and technology; v. 37)

"Proceedings of an International Symposium on Adhesives, Sealants, and Coatings for Space and Harsh Environments, sponsored by the Division of Polymeric Materials: Science and Engineering of the American Chemical Society, held April 7-9, 1987, in Denverr, Colorado"T.p. verso.

Includes bilbiographical references and index.

ISBN-13: 978-1-4612-8308-9

DOI: $10.1007 / 978-1-4613-1047-1$

1. Adhesives-Congresses. 2. Sealing compounds-Congresses. 3. Coatings-Congresses. I. Lee, Lieng-Huang, 1924- II. American Chemical Society. Division of Polymeric Materials: Science and Engineering. III. Title. IV. Series.

Proceedings of an International Symposium on Adhesives, Sealants, and Coatings for Space and Harsh Environments, sponsored by the Division of Polymeric Materials Science and Engineering of the American Chemical Society, held April 7-9, 1987, in Denver, Colorado

(C) 1988 Plenum Press, New York

Softcover reprint of the hardcover 1st edition 1988

A Division of Plenum Publishing Corporation

233 Spring Street, New York, N.Y. 10013

All rights reserved

No part of this book may be reproduced, stored in a retrieval system, or transmitted in any form or by any means, electronic, mechanical, photocopying, microfilming, recording, or otherwise, without written permission from the Publisher 


\section{PREFACE}

New technologies constantly generate new demands for exotic materials to be used in severe environments. The rapid developments of aerospace industries during the last two decades have required new materials to survive extreme high and low temperatures and various radiations. The exploration of new energy sources, e.g., solar and geothermal, has led us to develop new solar collectors and geothermal devices. Even the search for new oils has demanded that we study the corrosive environment of oil fields.

In the telecommunication industries, optical fibers have been adopted broadly to replace metallic conductors. However, none of the optical fibers can survive abrasion or corrosion without the application of a coating material. For microelectronics, protection in terms of coatings and encapsulants is deemed necessary to prevent corrosion. One of the major causes of corrosion has been shown to be water which appears to be abundant in our earthly environments.

Water can attack the bulk adhesive (or sealant), the interface, or the adherend. Water can also cause delamination of coating film, and it is definitely the major ingredient in causing cathodic or anodic corrosion. Thus, water becomes the major obstacle in solving durability problems of various materials in harsh environments.

As an intent to solve some of the above problems, an International Symposium on Adhesives, Sealants, and Coatings for Space and Harsh Environments was organized for the Division of Polymeric Materials and Engineering of the American Chemical Society. The Symposium was held between April 7 and 9, 1987 in the Radisson Hotel, Denver, Colorado. The meeting was well attended by those from academia and industries.

A total of 34 papers was presented to six sessions. The papers, which were properly refereed and revised, are now included in this volume of Proceedings, which also contains several contributions submitted after the Symposium and the discussions. This volume is divided into six parts:

I. Environmental Exposure

II. Stress and Interface

III. Adhesives for Space and Harsh Environments

IV. Sealants for Space and Harsh Environments

v. Coatings for Corrosive Environments

VI. Coatings for Electronic and Optical Environments 
As Chairman of the Symposium, I would like to thank our contributors; their biographies are attached at the end of this volume. I am also indebted to our Session Chairmen: Professor C.E. Rogers, Dr. W.D. Bascom, Dr. R.M. Evans and Dr. J.W. Holubka, for their assistance. I would like to thank $\mathrm{Dr}$. J. Scott Thornton, for his talk during the Symposium Banquet. I sincerely appreciate the skill of Ms. D.M. Costenoble in retyping all manuscripts for this volume. I appreciate the support of Xerox Webster Research Center for me to perform this task. I would like to thank Mr. F. Belli and his group of the Technical Information Center in assisting me to prepare author and subject indexes.

Acknowledgment is also made to the donors of the Petroleum Research Fund, administered by the American Chemical Society. Their funding partially assisted several overseas speakers to attend the symposium.

Lieng-Huang Lee April, 1988 


\section{CONTENTS}

\section{PART ONE: ENVIRONMENTAL EXPOSURE}

Introductory Remarks

Adhesives, Sealants, and Coatings for Space and Harsh Environments LIENG-HUANG LEE

\section{Plenary Lecture}

Effects of Environmental Exposure on Sorption and Transport

of Penetrants in Polymeric Materials

CHARLES E. ROGERS

The Mechanical and Water Absorption Behavior of Fluoroepoxy Resins S.J. SHAH, D.A. TOD AND J.R. GRIFFITH

Characterization of a Durable Inorganic Metal-to-Metal Adhesive Found in a Chinese Qin's Chariot Built Around 207 B.C. XIA WEN-GAN

The Investigation of Underwater Adhesives in the People's Republic of China

XIE JU-NIANG, ZHONG SONG-HUR, ZOU XIAO-PING, CHEN RU AND LU SANG-HENG

Sealing of Human Tubular Tissues with High Alkyl Cyanocrylate Adhesive XKM-2 and Its Effects--A New Sterilization and

Nonsurgical Technique

RUAN CHUAN-LIANG, LIU JIN-HUI AND QIN ZHAO-YIN

Discussion

PART TWO: STRESS AND INTERFACE

Introductory Remarks

CHARLES E. ROGERS

\section{Plenary Lecture}

Electron Bombardment Induced Crack Initiation and Crack Growth

in Polymers and Polymer Surfaces

J.T. DICKINSON 
An Experimental Arrangement to Estimate the Failure Behavior of an Uncrosslinked Polymer Under High Spatial Constraint

M. PARVIN AND W.G. KNAUSS

Finite Element Microscopic Stress Analysis of Filled

Polymeric Composite Systems

Chi-Tsieh LIU, RUSSELL LEIGHTON AND GREG WALKER

Inorganic Primers for Adhesive Bonding: A Status Report

R.A. PIKE AND F.P. LAMM

The Bonding and Hydrolysis of $\mathrm{Cr}$ (III) Fumarato Coupling Agent on Aluminum Surfaces Studied by Auger Electron Spectroscopy and $X$-ray Photoelectron Spectroscopy

CHARLES Q. YANG, THOMAS $H$. RAUSCH, STEPHEN P. CLOUGH AND

WILLIAM G. FATELEY

Investigation of Steel/Epoxy Adhesion Durability Using

Polymeric Coupling Agents I. Synthesis and Characterization of

EME Coupling Agents

R.G. SCHMIDT AND J.P. BELL.

Discussion

PART THREE: ADHESIVES FOR SPACE AND HARSH ENVIRONMENTS

Introductory Remarks

WILLARD D. BASCOM

\section{Plenary Lecture}

An Overview of Polymers for Harsh Environments: Aerospace, Geothermal and Undersea

PATRICK E. CASSIDY

Ultraviolet Curable Siloxane Elastomers

Y. OKAMOTO, D. CROSSAN, K. FERRIGNO and S. NAKOS

Evaluation of Adhesively Bonded Composite/Metal Bonds in

Simulated Automotive Service Environments

J.W. HOLUBKA AND $W$. CHUN

High-Temperature Organic Adhesives--A Review CHANG CHIH-CHING

Organotin and Organotitanium-Containing Polydyes for Color

Permanence, Reduction of Laser Damage and Biological Resistance

to Rot and Mildew

CHARLES E. CARRAHER, JR., VAN R. FOSTER, RAYMOND J. LINVILLE, DONALD F. STEVISON AND R.S. VENKATACHALAM

Synthesis and Characterization of Atomic Oxygen Resistant Poly(sil-oxane-imide) Coatings ISKENDER YILGÖR

PART FOUR: SEALANTS FOR SPACE AND HARSH ENVIRONMENTS 


\section{Plenary Lecture}

Effects of Environment on Performance of Polysulfide Sealants

D. BRENTON PAUL, PETER J. HANHELA AND ROBERT h.E. HUANG

\section{Plenary Lecture}

Durability of Silicone Sealants

MICHAEL J. OWEN AND JEROME M. KLOSOWSKI

Depolymerization of Polysulfides: The Development of Improved

Chemical Desealers

WALDEMAR MAZUREK AND D. BRENTON PAUL

Hot Melt Sealants Based on Thermoplastic Elastomers SUNG GUN CHU

Sealants, Waterproofing and Coatings for Concrete ROBERT M. EVANS

The Study and Use of Sealant on Quicksand Surface for

Stabilization and Afforestation of Desert Land

LU JI-QING, YAN TING-JU, PEI ZHANG-QIN AND LU CHUN-YANG

Discussion

PART FIVE: COATINGS FOR CORROSIVE ENVIRONMENTS

Introductory Remarks

JOSEPH W. HOLUBKA

Plenary Lecture

Determination of the Stresses and Properties of Polymer

Coatings

CHARLES L. BAUER, RICHARD J. FARRIS AND MENAS S. VRATSANOS

Influence of Composition and Film Thickness on Antifouling

Paints Bioactivity Containing Castor Oil

CARLOS A. GIÚDICE, BEATRIZ DEL AMO AND VINCENTE J.D. RASCIO

Corrosion Prevention in Metals Using Layered Semiconductor/

Insulator Structures Forming an Interfacial Electronic Barrier F.C. JAIN, J.J. ROSATO, K.S. KALONIA, AND V.S. AGARWALA

Adhesion Properties of Polyelectrolytes--Chemisorbed Zinc

Phosphate Conversion Coatings

TOSHIFUMI SUGAMA

Effects of Mechanical Deformation on the Photodegradation of Acrylic-Melamine Coatings

TRUC-LAM H. NGUYEN AND CHARLES E. ROGERS 
PART SIX: COATINGS FOR ELECTRONIC AND OPTICAL ENVIRONMENTS

Introductory Remarks

LIENG-HUANG LEE

Plenary Lecture

Optical Fiber Coatings

445

WILLIAM E. DENIS

Polymer Materials for Optical Fiber Coatings

455

TA-SHENG WEI

Consequences of Exposure of Optical Coatings to Reactive Gases and Energetic Particles

J.T. DICKINSON M.A. LOUDIANA AND A. SCHMID

Stabilized Acrylic Glazings for Solar Reflectors

H.H. NEIDLINGER AND P. SCHISSEL

Electroconductive Coating with Polyconjugated Systems

487

LU ZHONG-HE, CHEN JING-HONG, LI YAO-HUAN AND YANG YING-SONG

XIA WEN-GAN AND HANG LU

Microfabricated Structures for the Measurement of Adhesion

and Mechanical Properties of Polymer Film

MARK G. ALLEN AND STEPHEN D. SENTURIA

Discussion

CONTRIBUTORS

AUTHOR INDEX 